\title{
波浪中旋回時の非定常横摇れについてーII
}

\section{一 波浪レーダーを用いた遭遇波浪予測に基づく船体運動シミュレーションー}

\author{
西村 浩二*・平山 次清**・高山 武彦***平川 嘉昭***・ \\ デニス アミルトンノミヤマ****
}

\section{Unsteady Rolling Due to Turning Manoeuvre in Waves- II : Motion Simulation Based on Encounter Wave Prediction by Wave Radar}

\author{
Koji NISHIMURA, Tsugukiyo HIRAYAMA, Takehiko TAKAYAMA, \\ Yoshiaki HIRAKAWA and Denis Hamilton NOMIYAMA
}

\begin{abstract}
In the case where a ship runs in waves with turning maneuver, the rolling oscillation becomes apparently unsteady state due to the changes of the frequencies and angle of the encounter waves and can grow into large amplitude. Especially in severe sea condition, operators are demanded to predict the large waves that faces during and after turning maneuver to avoid the serious impact for stability. It is, however, very difficult in practice. In the 1st report, the authors studied the characteristics of unsteady rolling during turn in regular waves and consequently showed some parameters that effect to maximum heel angle.

Since the 1st report, we have tried to develop a practical system to predict the encounter waves and ship motion to assist the wave-avoidance-maneuver and accomplished the most part of it. Our latest system consists of wave radar and numerical motion simulation technique. So, this reports shows the outline of this system and some results of motion prediction. Additionally, the results of field tests are shown for validation of this system.
\end{abstract} Keywords : Wave-avoidance-maneuver, Encounter wave prediction, Motion simulation, Wave radar, Field test キーワード: 避波操船，遭遇波浪予測，船体運動シミュレーション，波浪レーダー，実海域試験

\section{1. 緒論}

旋回等の操縦運動を考慮した場合、規則波中であ っても波との出会い角が時々刻々変化することによ り船体運動は基本的に非定常となる。特に荒天海面 において大角度の変針を安全に行なうためには、変 針後のみでなく旋回中の動摇を予測することが操船 者に要求されるがこれは経験に頼るところが大きい。 著者らは小型船の荒天海面における安全確保という 観点から第一報 ${ }^{(1)}$ で規則波中を旋回する際の最大
横傾斜角について初期船速、波浪条件、転舵タイミ ング等の影響を数值シミュレーションにより検討し た。結果として転舵タイミングが横傾斜角に与える 影響をある波浪条件に対して示したが、実際の海面 は不規則波であり横摇れ角自身も船体の初期状態に よって変化するため必ずしも一般的な結論を導いた とはいえない。以降研究を継続する中で同研究室で

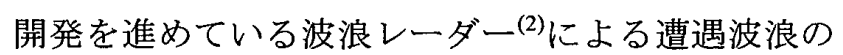
直前予測システムが理論的にはほぼ完成し、それに

\footnotetext{
* 学生会員 横浜国立大学大学院工学府博士課程 所属研究室 URL: http://www.seakeeping.shp.ynu.ac.jp/

** 正会員 横浜国立大学大学院工学研究院

*** 非会員 横浜国立大学大学院工学研究院

**** 非会員 横浜国立大学大学院工学府博士課程（研究当時）
} 
基づく船体運動のリアルタイム推定が可能になりつ つあるので、本論で現段階の成果を示す。このシス テムが完成すれば荒天操船を支援する有効なツール になると考えている。

本論のタイトルは研究の動機を同じくしているた め第一報を引き継いだが、主な内容は船体運動予測 結果の実船実験結果との比較であり、必ずしも旋回 中に限定したものではない。もっとも波浪レーダー は海域を面的に捉えるため旋回中であっても本シス テムによる運動予測は可能であるので、最後に旋回 中横運動の計算例を示し、実海域に相当する短波頂 不規則波海面での転舵タイミ゙ングを変えた場合の検 討を行う。

\section{2. 船体運動の数値シミュレーション}

数值シミュレーションの内容は 6 自由度運動方程 式を時間領域で解くものであり、変針、船速変化な ど操縦運動を考慮している点も第一報のものと変わ らない。ただし大波高中での計算精度を向上させる ため復原力の求め方など多くを改良している。入力 としての波浪方向スペクトルは後述する波浪レーダ 一による実海域計測值を用いた。

\section{1 座標系及び船体運動方程式}

本論では数值計算手法について概略のみ示す。詳 細は参考文献 (3) 参照されたい。

座標系は浜本の提唱した船体固定水平座標系 (Horizontal Body Axes System) を用いた ${ }^{(4)}$ 。この座 標系は従来操縦運動を記述するのに用いられてきた 船体固定座標系（General Body Axes System）と波浪 中運動に用いられてきた平水面固定慣性座標系

（Earth Fixed Axes System）双方の長所を取り入れた 形となっており、本座標系で定義された運動方程式 は、大きな回頭角と横傾斜角をもつ運動を従来の知

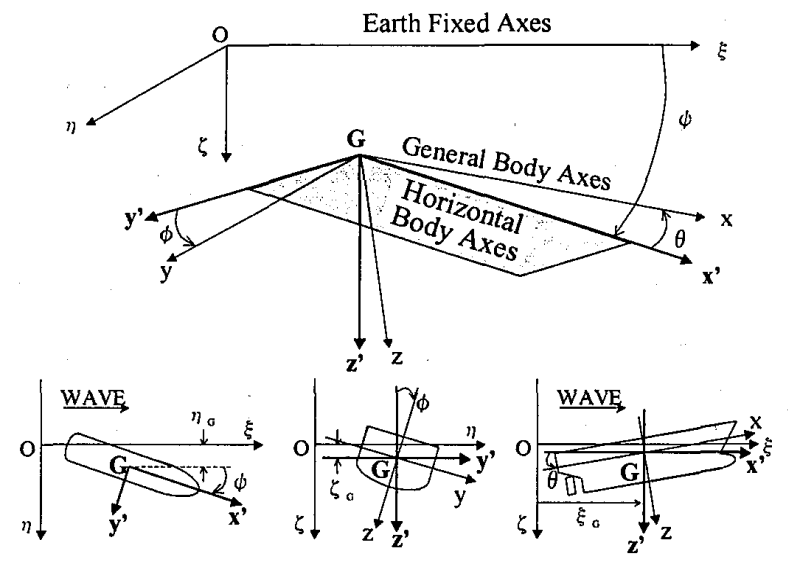

Fig.1 Co-ordinate systems
見で記述することが可能である。鉛直軸について下 向きを正としているため、後で示寸上下摇れ、波振 幅などの時系列でもマイナスのピークが波頂を示す。 本数值計算で用いた船体運動方程式を以下に示す。

\section{Translational Motion}

$$
\begin{aligned}
& \left(m+m_{x}\right) \dot{U}-m V \dot{\psi}-m_{y} V_{h} \dot{\psi}+m_{x} z_{G} \ddot{\theta}+X_{V \dot{\psi}} V \dot{\psi} \\
& =T(J)-R(u)+X_{F . K}^{\prime}+X_{R U D}^{\prime}{ }^{\prime} X^{\prime}{ }_{A I R} \\
& \left(m+m_{y}\right) \dot{V}+m U \dot{\psi}+m_{x} U_{h} \dot{\psi}+m_{y} x_{G} \ddot{\psi}-m_{y} z_{G} \ddot{\phi} \\
& +Y_{V} V_{h}+Y_{V V} V_{h}\left|V_{h}\right|-Y_{\dot{\psi}} \dot{\psi}=Y_{F . K}^{\prime}+Y^{\prime}{ }_{R U D}+Y^{\prime}{ }_{A I R} \\
& \left(m+m_{z}\right) \dot{W}+Z_{W} W_{h}+Z_{\ddot{\theta}} \ddot{\theta}+Z_{\dot{\theta}} \dot{\theta} \\
& =Z_{F . K}+Z_{R U D}+m g
\end{aligned}
$$

\section{$\underline{\text { Rotational Motion }}$}

$$
\begin{aligned}
& \left(I_{x x}+J_{x x}\right) \ddot{\phi}-m_{y} z_{G} \dot{V}_{h}-m_{x} z_{G} U_{h} \dot{\psi}+K_{\dot{\phi}} \dot{\phi}+K_{\dot{\phi} \phi} \dot{\phi}|\dot{\phi}| \\
& -Y_{h f} z_{G}=K_{F . K}^{\prime}+K_{R U D}^{\prime}+K^{\prime}{ }_{A I R} \\
& \left(I_{y y}+J_{y y}\right) \ddot{\theta}+m_{x} z_{G} \dot{U}_{h}+m_{z} x_{G} U_{h} \dot{\theta}+M_{\dot{\theta}} \dot{\theta} \\
& +M_{\dot{W}} \dot{W}_{h}+M_{W} W_{h}=M_{F . K}^{\prime}+M^{\prime}{ }_{R U D}+M^{\prime}{ }_{A I R} \\
& \left(I_{z z}+J_{z z}\right) \ddot{\psi}+m_{y} x_{G} \dot{V}_{h}+m_{y} x_{G} U_{h} \dot{\psi}-m_{y} z_{G} U_{h} \dot{\phi} \\
& +N_{V} V_{h}+N_{V V} V_{h}\left|V_{h}\right|+N_{\dot{\psi}} \dot{\psi}=N_{F . K}^{\prime}+N^{\prime}{ }_{R U D}+N^{\prime}{ }_{A I R}
\end{aligned}
$$

$x_{G} 、 z_{G}$ は重心から付加質量力作用点までの距離を 表し、T(J)はプペラによる推力で前進率の関数と して与える。 $R(u)$ は前進抵抗であり速力公試結果を 参考に速度の 3 次関数で与えた。右辺は外力項であ り、添字 $F . K 、 R U D$ 及び $A I R$ を有する項はそれぞれ 波、舵、風圧によるカ・モーメントを表すが動摇船 体による造波や波の擋乱などによる抵抗増加成分は 考慮していない。添字 $h$ で表す速度、加速度の項は それぞれ $x_{G} 、 z_{G}$ における值を表す。また $Y_{h f}$ は以下 に示すとおり船体横方向に働く流体力項である。

$$
Y_{h f}=Y_{V} V_{h}+Y_{V V} V_{h}\left|V_{h}\right|-Y_{\dot{\psi}} \dot{\psi}
$$

縦運動（ピッチ、ヒーブ）について、本研究では 原点を船体重心鉛直線上波面に持ち、船首方向及び 波面に追従して傾斜する座標系を考え（Fig. 2 の O” -x”y” $\mathrm{z}$ ”)、この上で表現される速度・角速度成分、 すなわち波面に対する相対的な運動からダンピング 成分を推定した ${ }^{(3)}$ 。曲面である波面に追従する平面 (x”-y” plane) は船体固定水平座標系の水平面 ( $x^{\prime}$ -y' plane）上で船体位置を示す 7 点（Fig. 2 に黒 点で示す。センターライン上の船長 4 等分点、及び ミッドシップの両舷側端点）に対応する波面の $\mathrm{z}$ 


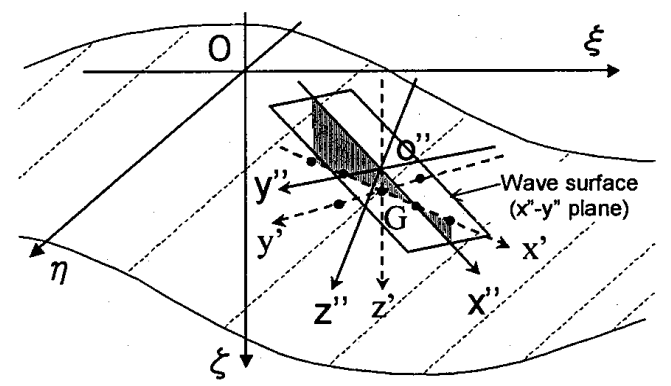

Fig.2 New co-ordinate system following to the mean wave slope ( $O$ "- $x " y " z ")$

座標から最小近似法によって求めている一種の平均 傾斜面である。これにより波長が短い縦波中などで 波面傾斜の過大評価を防止している。

本研究では比較的波長の長い波を想定しているた め、波浪外力としてフルードクリロフカのみを考慮 した。3 次元パネルで表現した船体表面上で圧力を 計算する際に相対的な波面変化による没水部形状の 変化も考慮している。構成するパネル数 $n$ に対する 波浪外力は以下のように計算している。各パネル面 $S_{n}$ の積分範囲は瞬時の没水部のみとした。ここで $p$ は静水圧を含む波圧を表す。

$\begin{array}{rlrl}X_{F . K}^{\prime} & =-\sum_{n} \iint_{\int_{n}} \frac{\partial p}{\partial x^{\prime}} d S_{n} & K_{F . K}^{\prime}=-\sum_{n} \iint_{S_{n}}\left[y^{\prime} \frac{\partial p}{\partial z^{\prime}}-z^{\prime} \frac{\partial p}{\partial y^{\prime}}\right] d S_{n} \\ Y_{F . K}^{\prime}=-\sum_{n} \iint_{S_{n}} \frac{\partial p}{\partial y^{\prime}} d S_{n} & M_{F . K}^{\prime}=-\sum_{n} \iint_{S_{n}}\left[z^{\prime} \frac{\partial p}{\partial x^{\prime}}-x^{\prime} \frac{\partial p}{\partial z^{\prime}}\right] d S_{n} \\ Z_{F . K}^{\prime}=-\sum_{n} \iint_{\delta_{n}} \frac{\partial p}{\partial z^{\prime}} d S_{n} & N_{F . K}^{\prime}=-\sum_{n} \iint_{S_{n}}\left[x^{\prime} \frac{\partial p}{\partial y^{\prime}}-y^{\prime} \frac{\partial p}{\partial x^{\prime}}\right] d S_{n}\end{array}$

舵及びプロペラの力を推定する際に波の流体粒子 運動による流入速力の変化は考慮したが、スラスト 係数は静水中の推定值を用いた。さらに本論では言 及していないが喫水線上の風圧特性を入力すること により風の影響を考虑することも可能である。

\section{2 検討対象船}

本研究では実海域実験及び模型実験を同時期に実 施した水産工学研究所所属の漁業調査船 $\left(\mathrm{L}_{\mathrm{pp}}=25 \mathrm{~m}\right.$, $\mathrm{B}=5.2 \mathrm{~m}, \mathrm{~d}=1.7 \mathrm{~m}, \Delta=131 \mathrm{ton}$ ）を検討対象とした。 Fig. 3 に本船の一般配置図及び数值シミュレーショ ンに用いたメッシュモデルを示す。このモデルは 2580 個の三角形要素で構成されており、一要素の平 均的なサイズは船長の $2.5 \%$ 程度である。

\section{3 波浪レーダー}

波浪レーダーについても装置や解析法の詳細は文 献 (2) 及びその参考文献を参照するものとし、本論で
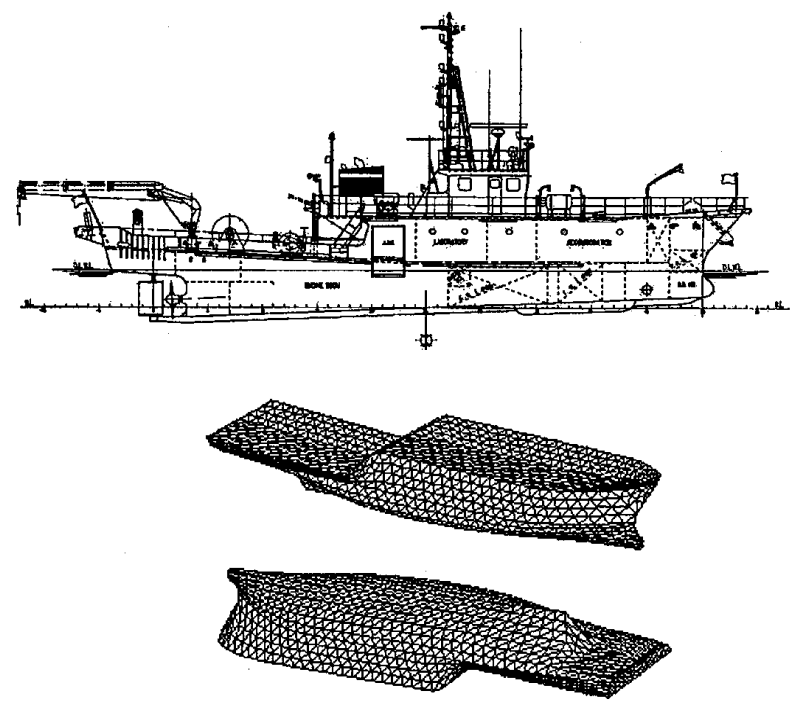

Fig.3 General arrangement \& 3D mesh model for numerical simulation.

はシステムの概要と解析手法について本研究用に試 みた部分のみを示す。

波浪レーダーシステム開発の動機は船舶における 遭遇波浪の信頼できる把握手法の確立にあった。波 浪は 2 次元的に広がっているため、例えば船載式波 高計による点計測では位相まで含む面的な性質を捉 えることは難しい。エルゴード性を仮定して船体動 摇から逆推定する方法 ${ }^{(5)}(6)$ も研究され一定の成果を 得ているが、直接的な計測法として一般的なものは 船員による目視観測のみというのが現状である。ま た人間が捉えきれない方向・周波数分布に関しても このシステムで計測可能であり当然夜間も有効であ る。さらに波浪を面的に捉える事は他の方法では難 しい追い波の計測においてもメリットがある。本研 究ではさらに歩を進めて個別波の推定を視野に入れ ている(2)。

今回開発したシステムは船舶に搭載される一般的 な航海用レーダーを用いるのが大きな特徴である。 これは新たに必要なハードウェアを最小限に抑える という点でメリットがある。この種のマイクロ波レ ーダーに含まれる海面反射はシークラッターと呼ば れ、水表面に風で生じる漣によって共鳴的に生じる 後方散乱と理解されており、通常はノイズとしてフ イルターで除去される。区射強度を極座標で表した PPI 画面上にシークラッターが波頂線を成す場合、2 次元フーリエ変換を用いて波数スペクトルを得られ るが、波以外の濃淡も評価してしまうおそれがあり、 さらに原点に対称なスペクトル形状となることから 波の主方向が一つに定まらないという問題も生じる。 本システムでは時間的に連続な PPI 画面（本研究で は 32 画面）を用いて (9) 式に示す 3 次元フーリエ変 
換により波数一周波数スペクトルを求め、さらに (10)式に示す波の分散関係を考慮したフィルターに より波成分だけを取り出している。

$$
\begin{aligned}
& F\left(k_{x^{\prime}}, k_{y^{\prime}}, \omega\right) \\
& =\iiint_{-\infty}^{\infty} \zeta_{w}\left(x^{\prime}, y^{\prime}, t\right) \cdot e^{-i\left(k_{x^{\prime}} \cdot x^{\prime}+k_{y^{\prime}} y^{\prime}+\omega t\right)} d x^{\prime} d y^{\prime} d t \\
& \omega_{e}=\sqrt{g k}+\vec{k} \cdot \vec{U}
\end{aligned}
$$

実測した PPI 画面のサンプルを Fig. 4 に、Fig. 5 には (10)式が示す分散関係が描く曲面を速力がある 場合（U=6kt）について例を示す。

以上の方法を用いて実用的なシステムを構築する には土夫すべき点が多数ある。開発段階では大きさ の異なる 4 種の船を装備対象として実海域実験を行 い、システムの有効性を検証するとともに解析法の 改良を行った。本論に関係する主な内容を以下に述 ベる。

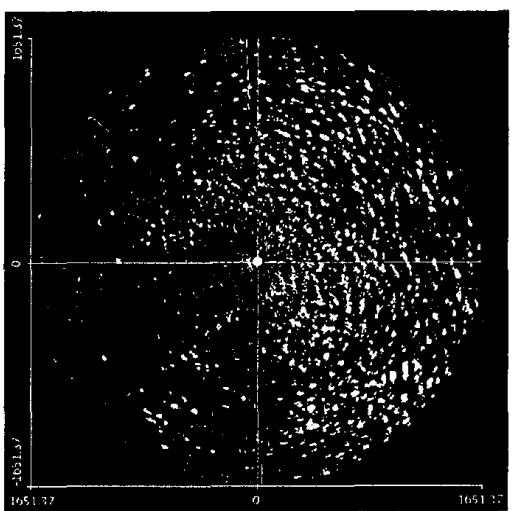

Fig.4 Real PPI Image obtained in field experiment

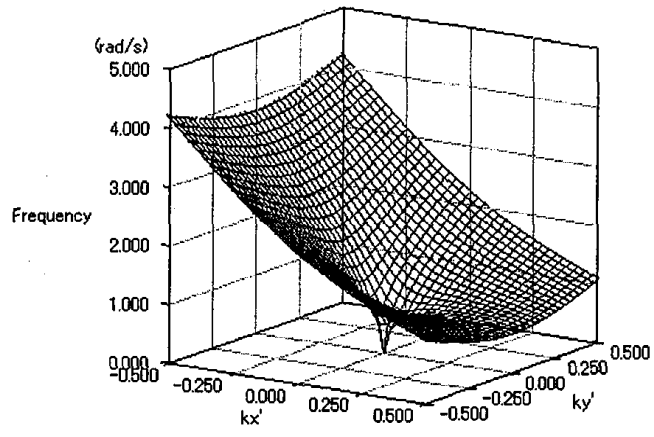

Fig.5 Dispersion shell with the Doppler effect $(\mathrm{U}=6 \mathrm{kt})$

\section{（1）解析エリアの設定}

本研究では数分先の遭遇波浪を予測することに本 システムを利用する。そのためには船速や波の方向 分布・群速度を考慮して PPI 画面上の解析エリアは 十分広いものでなくてはならない。レーダーの反射 強度は波による後方散乱の場合距離の 3 乗に反比例
するため、同一の波であっても PPI 画面上で一様に 分布しない。解析エリアを広くするとこの影響を受 けるが、特に装備位置の低いアンテナで顕著のよう である。さらにリアルタイム予測という性質を考え ると計算速度の制約を受けるため、広い解析エリア では空間の分解能が低下するという問題も生じる。 今回は解析エリアを本船を図心とする 1 辺 $1,792 \mathrm{~m}$ の正方形とし、 $256 \times 256$ に分割して解析を行ったが

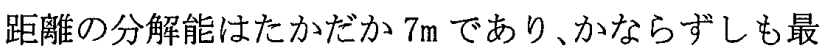
適とはいえない。

（2）周波数及び方向分割数

計算時間の制約は後の数值シミュレーションでも 考慮する必要があり、本システムから出力される方 向スペクトルは周波数成分 80 分割、方向成分 64 分 割とした。これは船体運動の計算結果を実船実験結 果と比較しながら決定した最小の值である。

（3）波高の推定

過去に波浪レーダーの研究では波高の推定法につ いてPPI 画面の陰影比を使う方法 ${ }^{(11)}$ 、陰影比から得 られた波高を船体運動により補正する方法 ${ }^{(12)}$ など が研究されている。後者が実用上有望と考えられる が、今回の検討では固定した補正值を用いてすべて の検討を行った。

（4）アンテナの装備位置

一般にこのシステムはレーダーアンテナが高い位 置に装備される方が有利であるが（一般に $15 \mathrm{~m}$ 以上 必要という認識がある)、本論の目的である荒天避航 に供する目的を考えると小型船を主対象とする必要 があり、理想的な装備位置は望めない。この点は装 備高さ $6.8 \mathrm{~m}$ の漁業調查船で 4 回に亘る実海域試験を 実施し有効性を確認した。本論で示すのはすべてこ の小型船の結果である。

（5）反射強度と波頂線の関係

波浪観測という目的では周波数領域のパワースペ クトル解析で十分であるが、時間領域の船体運動予 測まで行なうためには含まれる位相情報も重要であ る。一つにPPI 画面上に現れる波頂線（反射強度に

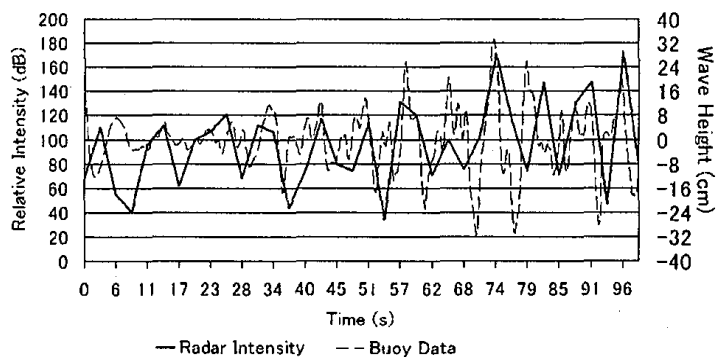

Fig.6 Wave Height / Radar Intensity Time History 

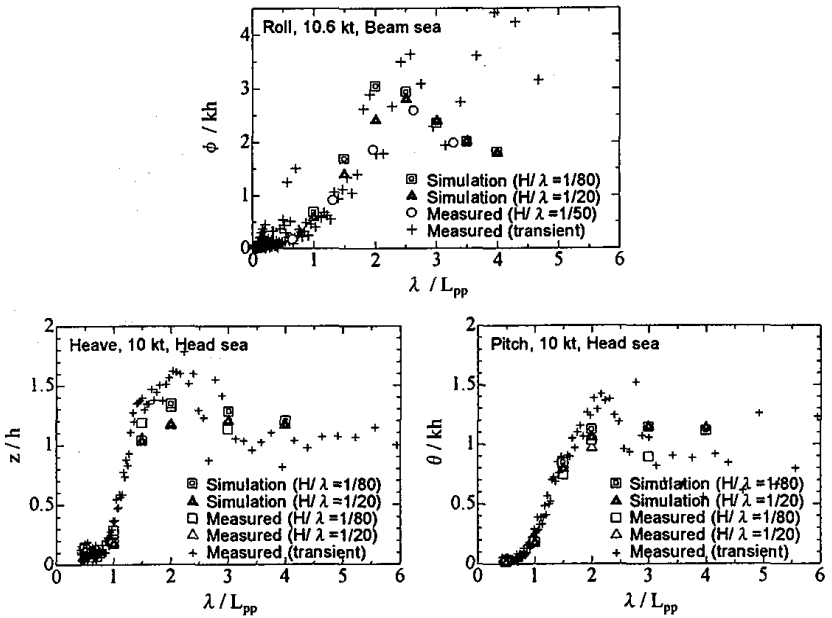

Fig.7 Frequency response function of roll, pitch and heave (simulation and model experiment)

よる）と実際の波頂線の空間的なずれについて考慮 する必要があり、これは小型の波浪ブイ(7)を用いて 実験的に検討した。Fig. 6 はブイ位置の反射強度と ブイの上下運動時系列を比較したものであるが、反 射強度による波頂線は実際の位置にほぼ対応してい るようである。

\section{4 模型実験結果との比較}

数值計算法の精度を確認するため模型実験結果と の比較を行った。プロペラ回転数一定で向い波航走 中のピッチ、ヒーブ、及び横波航走中ロールの波浪 応答関数を Fig. 7 に示す。実験では過渡水波 ${ }^{(13)(14)}$ をべースに規則波でも何点か計測を実施した。荒天 海象を想定して波岨度 $1 / 20$ まで比較を行ったが実 用上十分な精度を有するものと考えている。

次に操縦運動を含む大波高中船体運動の推定精度 を確認するため大波高規則波中（ $\lambda / \mathrm{L}=2, \mathrm{H} / \lambda$ $=1 / 15)$ 旋回運動について模型実験と比較した結果を Fig. 8 に実船スケールで示す。これは 3 種類の波長 船長比（ $\lambda / \mathrm{L}=1,2,3)$ について実験を行なった中 で旋回軌跡に関する推定誤差が最も大きい例である が、非常に険しい波浪中としては実用的な推定精度 を有するものと考えている。

模型実験はいずれも縮尺 $1 / 20$ の無線操縦模型 (3) を用いて、水産工学研究所の角水槽で実施したもの である。

\section{3. 実船実験結果との比較}

船体運動の計算結果について、実船実験結果との

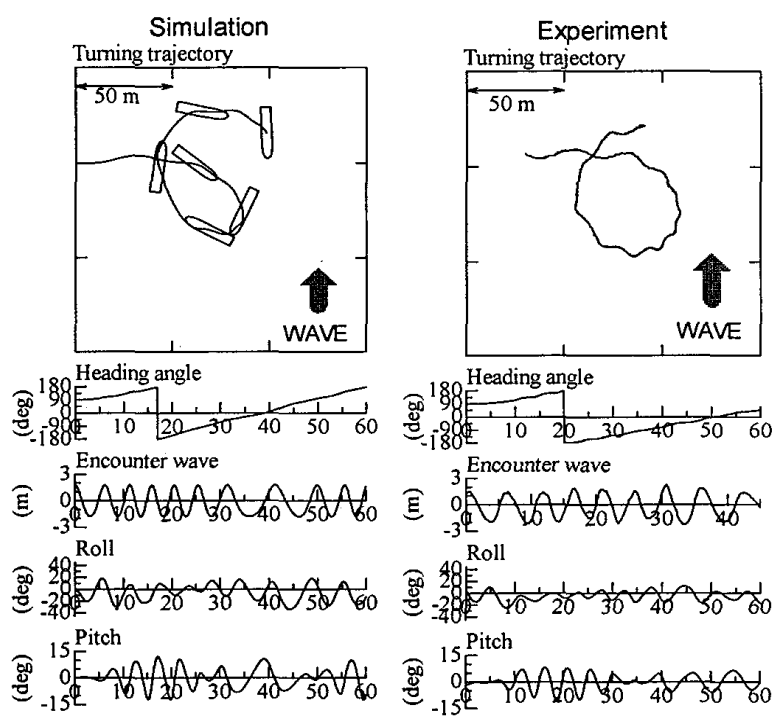

Fig.8 Turning trajectory and ship motion in regular waves (Rudder: $35 \mathrm{deg}, \quad \lambda / \mathrm{L}=2, \mathrm{H} / \lambda=1 / 15$ )

比較を行った。Fig. 9 は検討対象船 11 ノット八角形 航走試験中の 5 方位について、各方向直進中にレー ダーで計測した波のパワースペクトルとそれに基づ いて推定した運動シミュレーション結果を示すもの である。図中実線がシミュレーション、破線が船上 センサーによる計測結果を示す。波スペクトルの方 向分布は 0 が追い波方向、 $\pi$ が向い波を表すがこの ケースでは斜め追い波、真追い波状態で多くのノイ ズが見られた。周波数 $0.4 \mathrm{rad} / \mathrm{s}$ 以下は多くのノイズ を含むため計算に用いない。ここで示す船体運動シ ミュレーションはレーダーによる波浪計測と同一時 間帯の結果であり将来の運動予測とは異なる。ただ し前述のとおりレーダーは波浪を面的に捉えるため、 シミュレーションを打ち切らない限りこの先の時間 における遭遇波浪・船体運動の予測はほぼ同精度で 可能である。ここでは同時に計測した運動時系列と 比較するため表示時間領域を選択した。船体運動に ついて周波数・振幅特性は概ね推定できており、さ らに波スペクトルのノイズが少ない方位では位相を 含めてシミュレーションと計測結果の一致度は高い。 この結果は近い将来の船体運動を時間ベースで推定 できる可能性を示すものであるがいくつかの傾向・ 問題点も明らかになったので以下に示す。

（1）波浪解析には船の前進速度を用いるが対地速 力と対水速力を比較した結果、今回のケースでは後 者の方が遭遇波浪の予測精度が高いという結果を得 た。これは計測海域の潮流が比較的速いことに起因 すると思われる。

（2）波の方向分布について、主方向と逆行する成分 がいくつかのケースで計測された。これは 3 次元フ 
Head sea
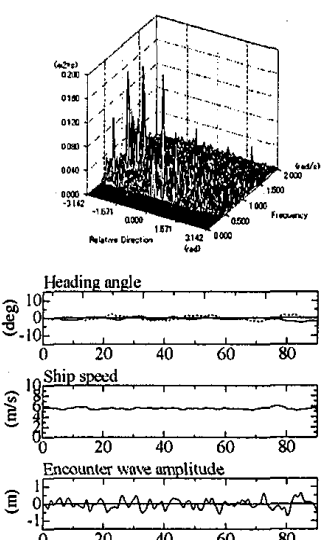

${ }_{4}$ Vertical acceleration of $G$

0.0 .40
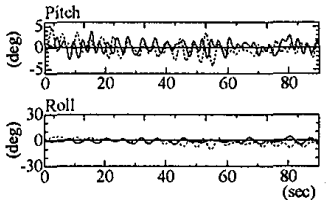

Bow sea
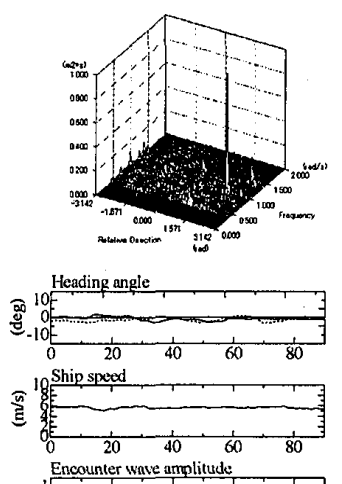

E :
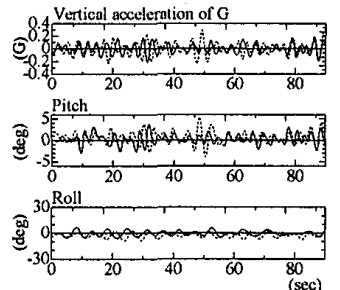

Beam sea
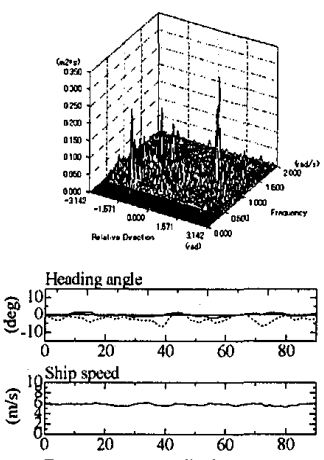

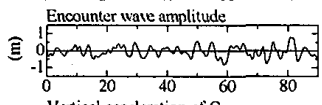
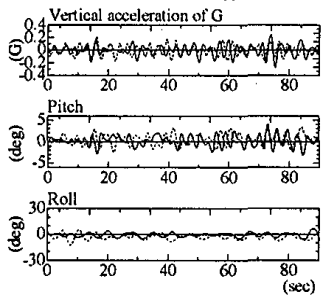

Quartering sea
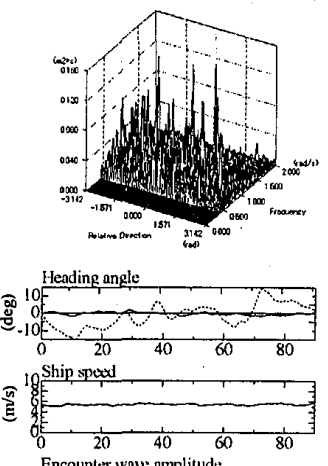

En
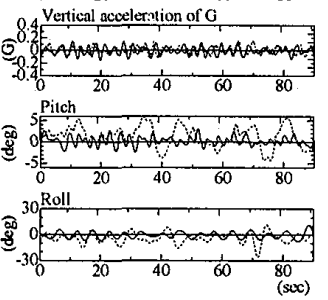

\section{- Simulation}

Following sea
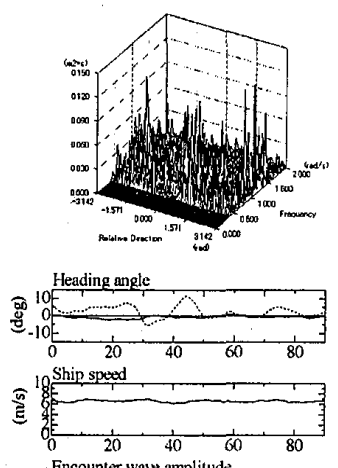

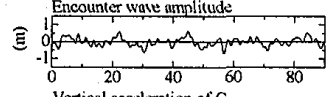
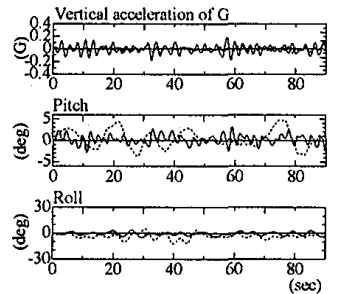

Field test

Fig.9 Measured wave spectra by radar and comparison of estimated and measured ship motion

(Ship speed is about $11 \mathrm{kt}$ )

ーリエ変換による進行波抽出に関する不具合であり、 レーダーの回転数が十分高くないこと、船体動摇の 影響を受けること等が原因と考えられる。

（3）追い波状態で計測波スペクトルにノイズが含 まれる例が多く見られたが、これはレーダー後方マ ストによるブラインドエリアや自船の航走波などに よる影響と思われる。

（4）連続する波群に含まれる大きな波のピークを 予測できない例が見られた。これは波高と電波の反 射強度がかならずしも線形関係でないことに起因す ると思われる。今回は計測中様々な試行の上、波頂 を捉えやすい表示反射強度やシークラッターフィル ターの調整を行なったが、計測したPPI 画面上の反 射強度はサチレーションを起こした状況であり、波 高を細かく分類するだけの分解能は有していない。 これは今後取り組むべき課題の一つと考えている。

\section{4. 旋回中横摇れ回避への応用}

本推定法では航跡予測に基づく遭遇波浪予測を行 っているため旋回等操縦運動も考慮することができ る。荒天避航（避波操船）のための大規模変針を想 定し、本システムを導入する効果について数值シミ こレーション上で検討した。Fig. 10 には 4 つの航跡 及び運動時系列を示す。時間軸の零、及び空間座標 の原点はそれぞれ自船の現在時刻・位置を示寸もの であり、操船者は現針路を維持した場合の航跡・運
動予測を監視しながら操船判断を行なうものとする。 想定した船速は 11 ノット、波の主方向は向い波であ る。今後 150 秒間の遭遇波浪及び船体運動の予測結 果は図中「Original course」のように与えられる。 有義波高が船長の $1 / 10$ に達し、上下加速度は頻繁に $0.5 \mathrm{G}$ を超える状況の中での反転避航を考える。一般 に荒天避航の手段として波との出会い角の選択、減 速、反転避航が挙げられるが ${ }^{(8)}$ 、特に巨浪中で反転 する際は波の合間をよく見計らうことが大事とされ

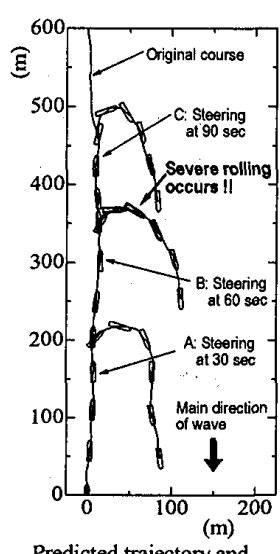

Predicted trajectory and Predicted trajectory and
location in every 10 secon

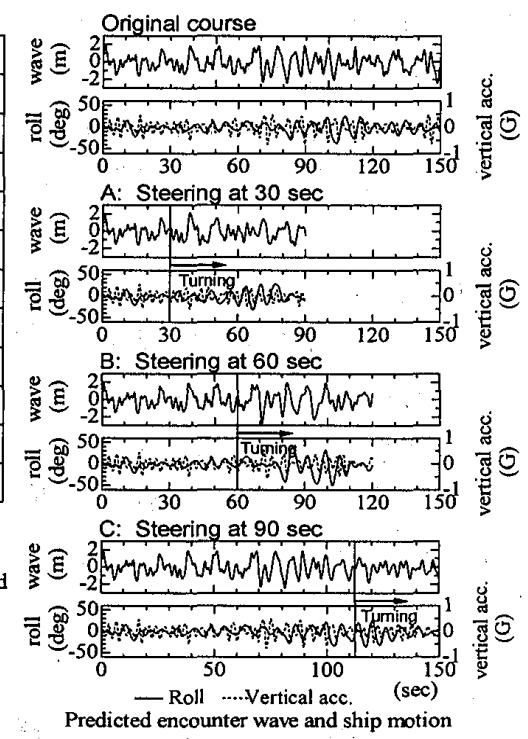

Fig.10 Predicted encounter wave and ship motion in assumed some courses 
る。シミュレーションは初期船首角を目標方位とし たオートパイロット（PD 制御）による直進状態から スタートし、30 秒後、60 秒後、90 秒後にそれぞれ 目標方位を反転させて旋回を開始させる。その後も オートパイロットを続けるが設定最大舵角は 35 度 であり、反転をほぼ終えるまでこの舵角で旋回を行 なう。最大横傾斜角に関して言えば 30 秒後に転舵し た場合の約 30 度に対し、60 秒後に転舵した場合は 約 50 度に達する。これは旋回中の出会い周波数や相 対風向により変化するため(ここでは風の影響を考 えていない）経験的な予測が難しいことから操船上 有益な情報になると考えている。ただし最適な転舵 タイミングを自動的に探索するような仕組みにはな っておらず、ここで示した予測をリアルタイムで行 なうためには並列計算などにより同時複数モデルの 高速計算を考えなければならない。これも今後の課 題としたい。

\section{5. 結論}

第一報では転舵タイミングと旋回中横傾斜角の関 係を決定論的に明らかにしようと試みたが規則波中 であっても初期状態により変化するため一般的な結 論を得ることは難しかった。現実的には本論で試み たような遭遇波浪の時間領域における予測が動摇を 考える上で極めて重要であり、本研究は従来操船者 の経験や勘に頼っていたこの要素を支援することを 目的としている。本論では波浪レーダーと船体運動 の数值シミュレーション技術を組み合わせることで、 将来の船体運動をリアルタイムで予測するシステム を開発し、実海域試験結果による評価を行なうこと で実現の可能性を示した。完成までにはなお多数の 克服すべき課題を残しているが現段階の結論として 以下にそれをまとめる。

（1）船体運動のリアルタイム予測のためにシミュレ ーションに要する計算時間をさらに短縮する必要 がある。

（2）レーダーの特性から無風の場合は波面からの反 射強度が著しく低下する。これを補う他のセンサ 一を考える必要がある。

（3）現在は行なっていないが GPS 信号により航走中 の自船位置を補正することで遭遇波浪の予測精度 向上が期待される。

（4） 3 章で挙げたレーダー信号解析上の問題点はす べて明らかにする必要がある。特に波群に含まれ る大きな単独波を予測できない現象についてはフ リーク波、三角波との遭遇予測という観点で重要 であり、始めに取り組むべき課題と認識している。

\section{謝辞}

模型及び実海域実験の実施にあたり多大なご理解 とご協力をいただいた(独)水産総合研究センタ一水 産工学研究所の山越康行所長、馬寧室長、松田秋彦 氏、たか丸乗員の皆様、ならびに加部東大悟君、小 山博之君をはじめとする横浜国立大学海空制御シス テム研究室メンバー全員にこの場を借りて謝意を表 したい。

\section{参考文献}

（1）西村浩二・平山次清：波浪中旋回時の非定常横 摇れについて I, 日本航海学会論文集第 108 号, pp.231-238, 2003.3

（2）平山次清ほか：遭遇波浪のリアルタイム把握法 と最新の成果, 試験水槽委員会シンポジウム, 日本造船学会, pp.74-87, 2003,12

（3）西村浩二・平山次清ほか：小型船の大波高中動 摇・操縦運動時間ベース計算法の一提案，日本造 船学会論文集 第 195 号, pp.204-210, 2004

（4）浜本剛実他：波浪中の操縦運動を記述する新し い座標系とその運動方程式, 日本造船学会論文 集第 173 号, pp.209-220, 1993

(5) T.Hirayama, M.Minami, K.Minami :

Estimation of Directional Wave Spectrum by a Running Ship -Optimization of Estimation Procedure-, 14th Ocean Engineering Symposium, SNAJ, pp.109-116, 1998

（6）井関俊夫ほか：船体運動データを用いた方向波 スペクトルの Bayes 推定(第 2 報); 日本造船学会 論文集第 176 号, pp.99-105, 1994

（7）平川嘉昭・高山武彦・平山次清 - 西村浩二：超 小型波浪ブイの近距離送信型への改良と計測例, 関西造船協会論文集第 241 号, pp.221-226, 2004.3

（8）植竹正雄：荒天避航の実例〔1〕，船舶の荒天運 航に関するシンポジウム, 日本航海学会, pp.99-120, 1973

(9) K.Nishimura, T.Hirayama : Maneuvering and Motion Simulation of a Small Vessel in Waves, MARSIM'03, 2003

(10) D.H.Nomiyama, T.Hirayama : Evaluation of marine radar as an ocean-wave-field detector through full numerical simulation, JMST, Vol.8. No.2, pp.88-98, 2003

(11) F.K.Takase, T.Hirayama, S.G.Park : Evaluation of Marine Wave Radar (Part II), 日 
本造船学会論文集第 188 号, pp.225-237, 2000

（12）平山次清・朴承根・平川嘉昭・高山武彦: 舶用 レーダーの波浪計化一ロバストな新システムの 提案・試行一, 日本造船学会論文集第 191 号, pp.51-56, 2002

（13）竹沢誠二・平山次清 : 任意過渡水波の発生につ いて, 日本造船学会論文集第 129 号, pp.247-259, 1971

（14）竹沢誠二他：耐航性に関する動的船型試験法, 第 2 回耐航性に関するシンポジウム,日本造船学 会, pp.83-108, 1977

\section{質疑応答}

水井真治（広島商船高等専門学校）:

発表された船体運動の予測結果（本文 Fig.9）に ついて第 4 方位（Quartering sea）、第 5 方位

(Following sea) の精度が悪い理由についてご教 示いただくとともに、この点についての今後の改善 対策を教えてください。

西村浩二 :

本研究を通じて波浪レーダーによる追い波中遭 遇波浪の推定精度に関してレーダーPPI 画面上解 析エリアの影響を強く受けることが分かりました。 現在は全方位からの波の到来を考慮した大きな解 析エリアを用いているため、多くの場合解析エリア 内で波頂線（波からの電波反射強度）が一様になら ず（風上側で強い反射強度を示す）、これに起因す る低周波ノイズが計測スペクトルに現れます。これ を解析上処理する際に同周波数帯の波成分にも影 響を与えたと思われ、これが追い波中船体運動の低 周波成分推定精度低下の原因と考えています。

考えられる対策の一つは解析エリアを船速、波の 方向分布・周波数帯によって最適位置に移動させる 方法で、この有効性は現在検討中です。他方、解析 エリア内の反射強度分布を一様にするフィルター を用いる方法も考えられますが、これはフリーク波 の識別などに影響を与える可能性があると認識し ています。 